\title{
SIMULATORS IN THE PROCESS OF FLIGHT TRAINING
}

\author{
Adam RURAK, Ph.D. \\ National Security and Logistics Faculty \\ Polish Air Force Academy \\ ul. Dywizjonu 303 no 35 \\ 08-521 Dęblin, Poland \\ a.rurak@wsosp.pl
}

\begin{abstract}
The article describes the use of air simulators in the process of training and further professional development of personnel. Aviation tasks are realized in an environment which is difficult for the human being. The process of training and flight enhancement is supported, to a larger extent, by simulation training. The process of theoretical and practical training must take place in conditions which are close to the situation occurring in real world as much as possible.
\end{abstract}

Keywords: pilot, air personnel, flight training, professional development, simulator, aircraft

\section{INTRODUCTION}

Flight training and development of pilots and ground personnel is a difficult process taking place in the air, in the environment which is unfriendly to the human being. Even basic research in this field demonstrates that the best effects in training and development of flight skills are achieved by training in conditions which are close to the real ones. By using flight simulators on the ground and in the air it is possible to achieve very satisfying results of training and significantly reduce training expenses. This article describes the main functions of air simulators used in this complex undertaking.

\section{BASIC FUNCTIONS OF SIMULATORS IN FLIGHT TRAINING}

The effectiveness of practical training on air simulators is determined by a number of factors such as security, economy, technology and methodology. The devices need to have a range of features due to the fact that they are to achieve a desirable level of efficiency of simulator training and make various applications. The basic, desirable functions of simulators for further training and professional development of pilots include:

- the demonstration function, referring to enriching the process of academic training with the elements which enable to practically demonstrate the student specific procedures, methods and manners of using the equipment, instruments and onboard systems.

- the educational function, referring to such elements as: shaping and improving the skills and habits of the student in the practical execution of operations in the cockpit, using operational procedures, dealing with an emergency situation on board an aircraft, improving teamwork skills in a multi-person crew, enhancing the skills of using air phraseology, shaping and developing training skills of flight instructors, etc.

- the personal function, related to shaping and developing required personal and professional features of pilots (undergoing training), which prepare them, among others, for the execution of air tasks under high workload conditions and/in time deficit conditions, including the conditions onboard or in the task environment of new situations from the perspective of the previous experience of the pilots who undergo training, etc.

- the adaptation function, which consists in improving, by the trained pilot, "repetitive" activities on board the aircraft, including those related to the activities in complex and emergency situations. The exercises carried out within this function are extremely relevant when preparing a pilot for the implementation of a new aviation task, from the standpoint of professional experience.

- the investigative function, connected with checking the trained pilot's behavior at each stage of realizing the planned aviation task, taking into account specific construction, ergonomic solutions or those in the automatization field for a specific type of aircraft. It also refers to validating theoretical assumptions related to a manner of solving a problem on board an aircraft by its crew, such as making correct assumptions with regard to the behavior of the crew in a particular emergency situation. This function is also applicable in case of a necessity to confirm the conclusions of the investigation committees relating to the causes of an occurrence of an air event.

- selective function, involving a permanent or temporary elimination from further flight training of persons with no predispositions (competence, knowledge, skills) for the pilot's job or specific aviation tasks.

- control-examination function, which facilitates control and examination exercises in relation to specific tasks or air licenses.

\section{SIMULATION TRAINING IN THE PROCESS OF TRAINING AND FLIGHT DEVELOPMENT}

Along with the increase in the complexity of avionics systems, control, navigation and other systems, the time 
necessary to master pilotage skills has been extended. The pilot's job and the work of ground personnel in aviation require perfection in action. Such perfection can be achieved only by gaining extensive knowledge and experience, and by mastering habits in flying. The aviation personnel, particularly the flying one, must possess a number of abilities that require constant improvement in the process of training and professional development.

The most important ones include:

- readiness for a professional response to changing situations,

- learning and remembering activities,

- the ability to focus on the task that has to be solved at a given moment,

- the ability to quickly perceive and assess in detail and in different situations,

- the ability of observation of data coming from multiple information sources at the same time, their integration and evaluation of time intervals,

- the ability to evaluate the relationship between speed and distance,

- the ability of visual-motor coordination,

- spatial orientation,

- precise cognitive and motor control,

- positive attitude to challenges and difficulties ${ }^{1}$.

Training in the air generates enormous costs and poses a constant threat in case of an error. This applies to all subsequent stages of flight training.

Luckily, human being is assisted in this process with results of engineering thought in the form of flight simulators of different degrees of complexity. Continuous training on simulators allows practicing skills and forming habits which are necessary to conduct difficult tasks in the air. Nowadays it is possible to extend their services also in the didactic process through the introduction of more and more technologically advanced air simulators. However, despite the technological development, an individual, an instructor ${ }^{2}$ plays the most important role in the process of flight training. Their knowledge, experience, organizational skills, planning, determining the role of textbooks in the training, as well as the use of other materials and didactic aids is invaluable. Flight simulators greatly enhance safety of training and reduce its costs.

Currently, the set of devices to support the educational process (provided along with a specific type of a helicopter/ aircraft or a combat trainer as an integrated training system) includes:

- computer systems for theoretical training of flying and technical personnel (the so-called Computer Based Training - $C B T)$, with interactive software which completes or replaces the classic manuals and textbooks for group or individual study,

- a group of specialist trainers referred to as procedural simulators (the so-called Part Task Trainers - PTT

1 B. Sasim, Elementy ergonomii kabin samolotów wojskowych, Warszawa, p. 22.

2 J. Półturzycki, Dydaktyka dorosłych, Warszawa 1992, p.179. or Cockpit Procedures Trainers - CPT), which are a kind of simple simulators to conduct training with the use of selected pieces of aircraft equipment and the use of its onboard systems, weapons and conduct in emergency situations,

- "full-sized" flight simulators, often called Full Mission Trainers (FMT) to conduct training in full extent of aircraft operation by the crew and the implementation of tasks which are basic for a given phase ${ }^{3}$.

However, out of a vast family of flight simulators of different technological solutions, the most important indicator of their use in the didactic process is their purpose.

The simplest model is a device of aerodynamic characteristics which imitates the properties of a jet plane, where the student practices actions necessary to learn how to control the aircraft in three planes. Another simple simulator can be a PC computer with basic pilotage software. On the screen the moving image of space and the earth simulates a flight; the student who maneuvers the joystick and rudder pedals masters the ins and outs of controlling an aircraft. Another simulator is a training device to learn instrument flying, airport approach systems, IFR procedures, radio communications and operation of the onboard computer FMC or other on-board systems.

The highest class are "full-fight" simulators imitating an appropriate type of an aircraft with the ability to simulate all maneuvers, operations in the cockpit, procedures, emergencies and malfunctioning of this type of an aircraft ${ }^{4}$, also allowing a reconstruction of crew activities, which may lead to incidents or air accidents.

Their design includes:

- the kinematic system controlled by a mobile platform in six degrees of freedom, allowing the pilot to receive almost all the sensations of motion dynamics of a simulated flight through sensory receptors for balance and kinesthesia,

- the visualization system affecting the sense of sight, (perspective image, spacious color view with a wide angle of projection), changing with the apparent motion of the aircraft over selected terrain at day and night with different visibility, cloudiness and light.

- the acoustic system affecting the sense of hearing, which generates any noises accompanying the flight (sounds of changes in aircraft configuration, engine dynamic, warning signals, alarm, aircraft vibrations and other) with a possibility of radio correspondence,

- cockpit of the simulator as an enclosed space, a faithful recreation of a simulated aircraft with all the equipment, on-board instruments, architecture of the interior, controllers and levers that work similarly to a plane and affecting the previously discussed systems so as to cause the reception of specific effects through pilot's sensory receptors as an actual flight.

3 J. Rajchel, A. Rurak, „Profesjonalne siły zbrojne w społeczeństwie XXI wieku”, Zeszyty Naukowe Wyższej Szkoły Oficerskiej Sit Powietrznych, Dęblin 2013, p.105.

4 M. Kaku, Fizyka przyszłości. Nauka do roku 2100, Prószyński i Spółka, Warszawa 2011, p. 53. 
The class of simulating devices called JAR-SIM as FNPT II (Flight \& Navigation Procedure Trainer-II), contrary to the name "simulator," is related to a specific type of an aircraft. Now it has become one of the main tools of the pilot-instructor.

The latest powerful simulation systems ensuring a high realism of training are used in military aviation. The modern AACMI system (Autonomous Air Combat Maneuvering Instrumentation $)^{5}$ ensures high realism of training. This system collects information from on-board equipment (sights and navigation, GPS) and has the ability to exchange data (LINK-16 system) with other aircraft and ground systems equipped with such a device. This allows making even a real "air battle" with the participation of a large number of aircraft and anti-aircraft systems, and then carry out any analysis of its results, using the data from these devices. The use of AACMI (e.g. The Flight Profile Recorder system manufactured by the German company BOBENSEEWERK $\mathrm{GmbH}$ ) allows improving a group battle conducted by the pilot (even in a complex tactical situation), as well as gaining experience, which in case of traditional methods is possible to gain only in a real dangerous fight.

Another solution, which is technologically modern and allows reducing the cost of training (such as weapons and ammunition), is the use of aircraft as a simulator during combat tasks. ${ }^{6}$ A virtual scenario, for example the tactical one, is prepared on ground equipment, and then using an appropriate medium, "uploaded" into the memory of the avionics of a helicopter or an aeroplane. During the flight the avionics devices "simulate" the activities of for example an enemy aircraft, by simultaneous registering the pilot's activities (e.g. firing simulated projectiles). All actions are thoroughly analyzed on the ground. This allows training a military pilot in combat missions in real conditions of stress and physical exhaustion. Such conditions cannot be simulated on any ground devices. The use of "virtual" armament in combat missions considerably reduces the cost of flight training. Imaging of the tactical situation, using for example LINK-16, unimaginably increases pilot's situational awareness. The changes in air training focus on unification of onboard armament.

On the other hand, the introduction of highly maneuverable combat aircraft into the military accelerated the implementation and development of a new class of devices known as dynamic flight simulators". It is a combination of a centrifuge with a module which simulates an aircraft cockpit of a given type. They are used:

- during the selection of candidates for training, checking the capability of high $\mathrm{G}$ loads and training techniques which are to enhance pilot's resilience,

- for the training of pilots flying on highly maneuverable planes,

5 T. Smolicz, ,Symulatory w szkoleniu lotniczym”, (in:) Materiaty Seminarium ,Symulatory w lotnictwie. Nowe technologie”, Warszawa 2008, p. 23.

6 J. Rajchel , A. Rurak, „Model funkcjonowania profesjonalnych sił zbrojnych w społeczeństwie XXI wieku”, Zeszyty Naukowe Wyższej Szkoly Oficerskiej Wojsk Lądowych, Wydanie Specjalne, Wrocław 2012, p. 84
- in advanced training with the implementation of a virtual tactical scenario prepared on ground devices, and by means of a medium, "uploaded" into the memory of the aircraft avionics. During the flight the avionics devices "simulate" the activities of the enemy in the air with simultaneous registering of the pilot's operation? ${ }^{7}$.

The issues of simulating a situation in which spatial disorientation of the crew can occur and then using exercises to teach how to avoid its results is realized in the process of flight training through the use of specially designed flight simulators. Spatial disorientation is a state of the pilot in which they are unable to assess or can wrongly assess the position of the aircraft in space. There are numerous causes of disorientation, e.g.: a manner of information processing by the brain, the imperfection of the construction of the senses of sight and balance, the concurrent reception of conflicting signals from the organ of vision by the brain, the middle ear and the inner perception, or the lack of adequate knowledge about the problems of the loss of spatial orientation. In training equipment it is relatively easy to simulate the state of disorientation. An example of a device that facilitates the demonstration and training in conditions which are conducive to spatial disorientation is the GYRO IPT II (GYRO Integrated Physiological Trainer, Generation II). An important feature of this device's motion system is the ability to smoothly generate cabin movements with angular velocity and acceleration and linear accelerations below the threshold of human perception as well as a continuous, unrestricted rotation of the cabin around its vertical axis. GYRO IPT II software contains several ready and easily customizable scenarios of demonstration and training, e.g. disorders of the assessment of motion caused by the Coriolis acceleration (the movement of the pilot's head towards the center of rotation of the aircraft), false sense of the aircraft rotation in the opposite direction after a recovery from prolonged spin; feeling of change in the bank angle after the cessation of the angular speed of bank (slow roll) with a value below the threshold of perception (the effects mainly arise from the imperfections of the middle ear), a false horizon (interpretation of diagonal and not upper horizontal or bottom edges of clouds or line of lights as the horizon line), the "black hole" effect during the maneuver of approach to landing at night (absolute loss of spatial orientation in the absence of visible objects of the surroundings e.g. due to unexpected entering clouds), erroneous assessment of the distance from the runway with other dimensions than the runway displayed previously.

Training in high acceleration conditions is achieved by the centrifuge, in which the pilot cockpit is designed as a faithful copy of the aircraft cabin so as to enable the pilot simulation. ${ }^{8}$ An example of a "simulator placed in a centrifuge" is ETC GL 6000 (Gyro Lab Model 6000). The cabin has six degrees of freedom: total rotation, roll,

7 R. Hać, M. Kozub, A. Rurak, Udzial lotnictwa w operacjach polaczonych pierwszych dekad XXI wieku, Wydawnictwo WSOSP, Dęblin 2012, p. 84 .

8 S.Z. Kerns, E-learning in Aviation, ASHGATE, Farnham 2010, pp. $3-10$. 
pitch, yaw and horizontal and vertical linear motion. The software of the computer system of the device allows simulations of high-manoeuver aircraft such as the F-35B Lightning II, vertical takeoff and landing and V-22 Osprey transport aircraft. It is possible to simulate transient states, characteristic for these aircraft ${ }^{9}$. The device enables the implementation of advanced training of high tolerance, unusual and long-term overload, training in a situation of space disorientation caused by high overloads, and investigation of bodily response to overload.

Long years of analyses of air catastrophes and accidents in the USA have proved (e.g. studies made by Dr. Kent Gillingham, US Air Force) that various types of spatial disorientation of military and civilian crews lead to the majority of catastrophes and accidents. These studies have shown that it is possible to eliminate crew errors resulting from spatial disorientation through continuous pilot training on spatial disorientation in the first phase of the training, avoidance of its results and regular crew training in conditions which lead to the occurrence of disorientation by using ETC GYRO IPT II or GL 6000 simulators.

In the process of training and professional development of pilots and ground staff, training on simulators takes a major portion of the training plan. The possessed aviation simulators allow:

- preliminary selection of candidates,

- basic flight training and cabin crew training,

- professional development for pilots and cabin crew,

- learning combat on a given type of an aircraft,

- training air traffic control and ground personnel,

- training Ground Control Interception of air and ground targets,

- training technical personnel to maintain aircraft,

- research and development in the field of aeronautics, weaponry, air traffic management and air defense systems, aviation medicine ${ }^{10}$.

Air simulators make it possible to practice the abovementioned tasks in a variety of weather conditions, day and night.

In the process of training and skills development for pilots and other aviation personnel, other devices are also used. An example might be a training device for learning ejection from the aircraft TS-11 "ISKRA" or a training device for learning ejection from the ground - UTKZ.

Training on the training device for learning ejection from the aircraft TS-11 "ISKRA" allows:

- acquiring the habits of handling the ejection seat in an aircraft,

- shaping the correct patterns of behavior in case of making a decision to eject,

- shaping and consolidating the necessary habits in the process of emergency leaving the aircraft.

9 T. Smolicz, „Symulatory w szkoleniu lotniczym”, (in:) Materiaty Seminarium , Symulatory w lotnictwie. Nowe technologie”, Warszawa 2008, p. 12.

10 B. Sasim, Elementy ergonomii kabin samolotów wojskowych, Warszawa, p. 26.
The training device to eject from the ground (UTKZ) allows:

- shaping the necessary habits during emergency leaving an aircraft,

- elimination of fears and psychophysical inhibitions before making a decision to leave an aircraft.

Young cadets who fly on planes equipped with ejection seats undergo training on UTKZ. The training is conducted once a year, a total of four trainings during studies. The ejection height with the pilot equals approximately 7 to $9 \mathrm{~m}$, with $8 \mathrm{G}$ force.

By using the training device to eject perfectly, it is possible to acquaint students with a dangerous situation, practice skills as well as developing habits.

\section{SIMULATION TRAINING AS A FUNCTION OF AVIATION SKILLS}

The continuation of the use of simulators by welltrained personnel requires continuous simulator training. The training is carried out on the "full flight" simulator and usually lasts several hours a year. The training is aimed primarily at raising skills of a crew in emergency situations. Besides the purpose of training should cover:

- the introduction of new elements of cooperation in the crew arising from the analysis of incidents,

- continuous enhancement of skills, particularly after the introduction of new aircraft equipment,

- practicing the implementation of e.g. new air traffic procedures,

- continuous introduction of new emergency procedures,

- preparation of the crew for flights for example in a different configuration - reduction of the number of crew, etc.,

- improvement of skills in order to avoid similar events, for example, through the reconstruction of an accident or incident,

- conducting complementary training sessions, for example for crews carrying out relatively few air operations,

- conducting other exercises necessary for professional development.

During the implementation of training with air simulators, it is essential to use the experience up to date with regard to the execution of the tasks and training, as well as obeying the following practical rules:

- each training in the simulator or a different training device should always be preceded with giving instructions, for instance during a briefing the pilot is familiarized in detail with the planned task and the way of its execution suggested by the instructor,

- if the planned task is new and rather difficult, and there appears a risk of exceeding the pilot's skills, the manner of accomplishing such a task must be well planned and demonstrated by the instructor,

- if the task is complex and requires a perfect performance for example at a specific time, the exercise must be 
executed so as to achieve the desired effect, regardless of the duration of such training,

- the next task must be commenced only after mastering the previous one in order to consolidate other new habits required for the execution of subsequent tasks,

- on simulators and training devices it is essential to maintain daily documentation such as: flight plans, checklists, airport sketches, standard operating procedures and other in order to improve the training by the instructor,

- during the exercises on the simulator, all explanations, comments and remarks made by the instructor should be made after a flight,

- during the exercises on the simulator, the instructor should show the student that a committed and not corrected error can entail the next errors, leading to dangerous situations. Learning through elimination of one's own mistakes, particularly in practical training, is the best method.

The process of supporting the system of training aviation specialists with devices which simulate the working environment or combat environment has the following advantages and disadvantages.

Advantages:

- possibility to become acquainted with hazardous emergency situations, which cannot be practiced on a real aircraft,

- reduction of the volume of traffic at the airport by reducing training flights by increasing the proportion of training on air simulators,

- simulation practice is not burdensome to the environment nor does it affect the ecology.

- it significantly reduces the training costs.

The drawbacks include the inability to simulate:

- the bulk of the sensations experienced by the pilot in the same exercise during a real flight,

- olfactory sensations e.g. accompanying a fire,

- part of kinesthetic sensations,

- sensations associated with the decompression of the cabin, fuselage, for instance temporary loss of hearing, earache, decompression haze,

- stress, the results of which, in a real flight when danger occurs, are hard to predict.

Flight simulators are very helpful in training and development of flight skills, however, they are still insufficient to fully simulate the real course of the flight with actual feelings and sensations of the crew.

Practical training completes a given phase of pilot training and ground personnel. The stage is costly, therefore every minute spent in the air should be used effectively. Thus, every practical exercise in the air, every flight must be preceded by a detailed preparation for flights by experienced instructor staff, and commanders. After the execution of the practical tasks in the air, there is always a debriefing of the course of these exercises in order to consolidate the experiences and current possibilities to implement the aviation training.

\section{CONCLUSIONS}

The presented in the article examples of the applications of new technologies in the process of training and a comprehensive preparation for air competencies allow a significant reduction of training costs as well as shortening the time of learning. In addition, modern technologies ensure training conditions close to those the pilot can face in a real task.

Thanks to modern technologies, it is possible to make an objective assessment of the results of practical air training.

\section{BIBLIOGRAPHY}

1. Endelsey, M.R., A Taxonomy of Situational Awareness Errors, (in:) R. Fuller, N. Johnston, N. McDonalds (eds.), Human Factors in Aviation Operations, Ashgate, England 2005.

2. Friedman, G. Następne 100 lat. Prognoza na XXI wiek, $\mathrm{AMF}+$, Warszawa 2010.

3. Hać, R., Kozub, M., Rurak, A., Udziat lotnictwa w operacjach połaczonych pierwszych dekad XXI wieku, Wydawnictwo WSOSP, Dęblin 2012.

4. Kaku, M., Fizyka przyszłości. Nauka do roku 2100. Prószyński i S-ka., Warszawa 2011.

5. Kerns, S.Z., E-learning in Aviation, ASHGATE, Farnham 2010.

6. Klein G., Studying Situational Awareness in the Context of Decision-Making Incidents, paper presented at the Experimental Analysis and Measurement of Situational Awareness Conference, Daytona Beach 1995.

7. Klich E., Szczygieł J., Bezpieczeństwo lotów w transporcie lotniczym, PIB, Radom 2010.

8. Półturzycki J., Dydaktyka dorostych, WSiP, Warszawa 1992.

9. Rajchel J., Rurak A., Model funkcjonowania profesjonalnych sił zbrojnych w społeczeństwie XXI wieku, Zeszyty Naukowe Wyższej Szkoty Oficerskiej Wojsk Ladowych, Wydanie Specjalne, Wrocław 2012.

10. Rajchel J., Rurak A., Profesjonalne siły zbrojne w społeczeństwie XXI wieku, Zeszyty Naukowe Wyższej Szkoty Oficerskiej Sit Powietrznych, Dęblin 2013.

11. Sasim B., Elementy ergonomii kabin samolotów wojskowych, ITWL, Warszawa 2008.

12. Smith K., Hancock P.A., Situational Awareness is Adaptive, Externally Directed Consciousness, (in:) R.D. Gilson, J.M. Koonce (Eds.), Situational Awareness in Complex Systems, Embry-Riddle Aeronautical University Press, Florida 1994.

13. Smolicz T., Symulatory w szkoleniu pilotów, Materiały Seminarium „Symulatory $w$ lotnictwie. Nowe technologie”, Warszawa 2008.

14. U.S. Army Technical Manual (1941) from: P. Renshaw, ATSB course materials: The Human Factor, Australian Transport Safety, Canberra 2006. 